\title{
Resprouting Ability of Dry Forest Tree Species after Disturbance Does Not Relate to Propagation Possibility by Stem and Root Cuttings
}

\author{
Daniel L. M. Vieira, ${ }^{1,2}$ André G. Coutinho, ${ }^{1,3}$ and Gustavo P. E. da Rocha ${ }^{1}$
}

\begin{abstract}
Tropical dry forest tree species are recognized for their high resprouting ability after disturbance. We tested whether species that commonly produce root and stem suckers can be propagated by large stem and root cuttings, a useful method for landscape restoration programs. We performed four experiments: (1) In a greenhouse, we tested the propagation of six species using large stem cuttings collected from early successional sites. We used the following treatments: (i) dry season collection and planting; (ii) dry season collection, storage in humid soil, and wet season planting; (iii) wet season collection and planting; and (iv) wet season collection and planting after treatment with commercial NAA auxin. (2) Stem cuttings of Myracrodruon urundeuva were planted in a pasture during the rainy season after either NAA, IBA, or no auxin treatment. (3) As a control experiment, we also planted
\end{abstract}

cuttings of Spondias mombin, a species known for successfully regenerating from cuttings. (4) Root cuttings of six species were collected in recently plowed pastures and planted in the greenhouse with and without treatment with NAA auxin. No root cuttings rooted. Only $M$. urundeuva and Astronium fraxinifolium stem cuttings rooted. Maximum success was obtained for stem cuttings collected and planted in the dry season (23\%). Only $13 \%$ of $M$. urundeuva had sprouted by the 15th month of the field experiment. As a result, large cuttings are not recommended for propagation of the studied species. Future studies should include development of suitable methods of root harvesting and prospection of traditional knowledge for species selection.

Key words: live fence, seasonally deciduous tropical forests, stakes, vegetative propagation.

\section{Introduction}

Growing trees by using large stem and root cuttings is a common technique, used around the world to propagate fruit trees while maintaining desirable genotypes and enabling precocious fruit production (Hartmann \& Kester 1975). This technique is also used to quickly establish live fences (Budowski \& Russo 1993; Choudhury et al. 2005). However, the use of large cuttings has been mostly neglected in restoration ecology (de la Cerda 1999; Zahawi 2005), despite clear advantages over nursery seedlings: (1) started plants can be larger, overcoming the herbaceous layer and cattle herbivory; (2) plants have higher growth rates and earlier reproduction, which modifies the habitat structure and attracts animals more quickly; and (iii) costs are lower, because cuttings do not require a nursery stage (Zahawi 2005; Zahawi \& Holl 2009).

${ }^{1}$ Laboratório de Ecologia e Conservação, Embrapa Recursos Genéticos e Biotecnologia, Brasília, DF 70770-917, Brazil

${ }^{2}$ Address correspondence to D. L. M. Vieira, email daniel.vieira@embrapa.br

${ }^{3}$ Graduação em Biologia, Universidade de Brasília (UnB), Brasília, DF 70919-970, Brazil
Two factors explain the rarity of tree propagation by cuttings in ecological restoration and silvopastoral and agroforestry systems. First, there is little knowledge of successful techniques and candidate species. While in Central America live fencing is a common practice among farmers, in Brazil this practice is incipient (Miranda \& Valentim 1998; Nascimento et al. 2009), and there is little information about the local native species and proper techniques for propagation by large cuttings. Second, propagation by cuttings causes undesired genetic homogeneity, because many cuttings are taken from a few trees. This is a cause for concern because genetic diversity of populations is one of the goals of ecological restoration.

This study investigates the potential of root and stem cuttings for tree propagation of dry forest species of central Brazil. Tropical dry forests are known for the abundance of tree species with high resprouting ability after disturbances such as fire or plowing (Vieira et al. 2006; Sampaio et al. 2007; Mostacedo et al. 2009). High resprouting ability of established trees suggests good potential for rooting of cuttings, although these two traits may not be strongly correlated (Itoh et al. 2002). Finding successful species and techniques for the vegetative propagation of native plants would contribute greatly to the increase of vegetation cover in tropical dry forests, by 
reducing the costs of ecological restoration and encouraging the adoption of silvopastoral practices. In addition, root and stem cuttings are readily available as a consequence of the pastoral management system used in central Brazil. In general, these pastures are renewed every 8 years through soil plowing and grass seeding, because fast colonization by trees suppresses desirable grasses (Hermuche et al. unpublished data). These pastures are abundant in tree poles that can be harvested before plowing, and roots can be easily collected after plowing to be used as propagules.

Multiple factors influence the successful establishment of cuttings, such as species, cutting age, size and lignification, season of collection and planting, auxins and water availability (e.g. Lebude et al. 2004; Zahawi 2005; Perrando \& Corder 2006; Rios et al. 2012). In our system, the timing of stem collection and planting is the most urgent question to be tested. Dry season collection of cuttings is advantageous because of high starch storage during the deciduous season (Latt et al. 2001; Newell et al. 2002), and because dormant buds are available to sprout after the first rains (Borchert 1994). However, during the dry season there is no water available in the soil to promote sprouting of the cutting. If cutting collection happens at the beginning of the rainy season, starch content has already been used to produce new leaves. However, this is the best time to plant because of water availability. Another important factor to consider for cutting collection is stem size. In order to use cuttings to build live fences or to overgrow grasses, we standardized stem length to $2.5 \mathrm{~m}$ (Zahawi 2005). Lastly, planting cuttings should be as simple as possible to provide practical guidelines for farmers and restorationists.

We performed four different experiments with the aim of exploring the propagation potential of dry forests tree species through cuttings. (1) In a greenhouse experiment, we tested six species using stem cuttings collected from early successional sites. We used four treatments in this experiment: (i) dry season collection and planting; (ii) dry season collection, storage in humid soil, and wet season planting; (iii) wet season collection and planting; and (iv) wet season collection and planting with commercial NAA auxin. (2) Stem cuttings of Myracrodruon urundeuva were planted in a pasture at the onset of rainy season. Cuttings were treated with either NAA, IBA, or no auxin. (3) As a control for our methods, we planted poles of Spondias mombin, a species known to propagate from cuttings. (4) In another greenhouse experiment, root cuttings of six species were collected in the late dry season from recently plowed pastures and were planted with or without treatment by NAA.

\section{Methods}

\section{Areas of collection}

For most experiments, cuttings were collected in São Domingos and Flores de Goiás, located in the Paranã River Basin in northeastern Goiás State $\left(13^{\circ} 38^{\prime}-14^{\circ} 26^{\prime} \mathrm{S}\right.$ and $46^{\circ} 41^{\prime}-47^{\circ} 00^{\prime} \mathrm{W}$ ), a major deciduous forest patch of Central
Brazil (Ratter 1992). Topography is flat with an altitude of about $500 \mathrm{~m}$. Geology is limestone, and the soil is rich in $\mathrm{Ca}$ and $\mathrm{Mg}$. The average annual rainfall is $1,236 \mathrm{~mm}$, with $89 \%$ of the rainfall occurring between October and March (compiled from hidroweb.ana.gov.br). The annual average temperature is above $23^{\circ} \mathrm{C}$, constant throughout the year (see a complete site description in Vieira \& Scariot 2006). Livestock is the main economic activity, and deforestation rates for pasture establishment are high.

For experiment 2, cutting collection and planting were carried out in the Paranaíba River Basin in southeastern Goiás State, in Cumari County $\left(18^{\circ} 20^{\prime} \mathrm{S}\right.$ and $\left.48^{\circ} 03^{\prime} \mathrm{W}\right)$. This region forms a vegetation mosaic where savannas occur on arenitic soils, semideciduous forests on basaltic soils, and deciduous forests on granitic or gneissic shallow soils (BRASIL 1983). The landscape includes flat ridge tops and $\mathrm{V}$-shaped valleys. Altitude is $650-750 \mathrm{~m}$. Average annual rainfall is $1,522 \mathrm{~mm}$, with $88 \%$ of the rainfall occurring between October and March, and annual average temperature is $23^{\circ} \mathrm{C}$, which is constant throughout the year (compiled from hidroweb.ana.gov.br). More than $50 \%$ of the land is occupied by planted pastures (www.seplan.go.gov.br/sepin). The collection area is a 13-year-old successional forest dominated by Myracrodruon urundeuva poles, regenerating from an abandoned pasture. The cutting collection for this study was licensed by the Brazilian System of Authorization and Information on Biodiversity (SISBIO Number 24277-1).

Farmers establish new pastures and restore pastures invaded by woody regrowth by felling trees with bulldozers, plowing the soil, and sowing grass. Immediately after plowing, which occurs in mid- to late dry season, root-crown resprouters can be seen in the bare soil in densities of up to 1.8 sprouts $/ \mathrm{m}^{2}$ (Vieira et al. 2006). We collected poles (juvenile trees circa $3 \mathrm{~m}$ high) from three old pastures (early successional forests; Fig. 1a) before bulldozing and plowing. We collected root pieces of root-crown resprouters in the bare soil of three pastures after plowing (Fig. 1b). It is worth mentioning that collecting poles does not affect pasture renewal, and collecting roots helps farmers prevent sprouting and subsequent competition with planted grasses in the following years.

\section{Experiment 1: Greenhouse Experiment With Pole Cuttings of Six Tree Species}

We collected pole cuttings of six tree species (Table 1). Species selection was based on high abundance of poles in early successional forests and high economic value for timber or nut (Dipteryx alata). Cuttings were collected using a machete to fell poles $4.5 \pm 0.3 \mathrm{~cm}$ in diameter (mean $\pm \mathrm{SE}$ ) at $50 \mathrm{~cm}$ height. Branches and tops were clipped to transport cuttings as $2.5 \mathrm{~m}$ long poles. Cuttings were transported to a greenhouse in the Federal District $\left(15^{\circ} 43^{\prime} 51^{\prime \prime} \mathrm{S} 47^{\circ} 54^{\prime} 07^{\prime \prime} \mathrm{W} ; 270 \mathrm{~km}\right.$ from the collection areas) in a truck lined with mattresses; cuttings were interspersed with bubble wrap. They were stored vertically under shade for up to 5 days before being planted in $18 \mathrm{~L}$ pots filled with soil brought from the same areas of root collection, in a greenhouse covered by transparent plastic. 

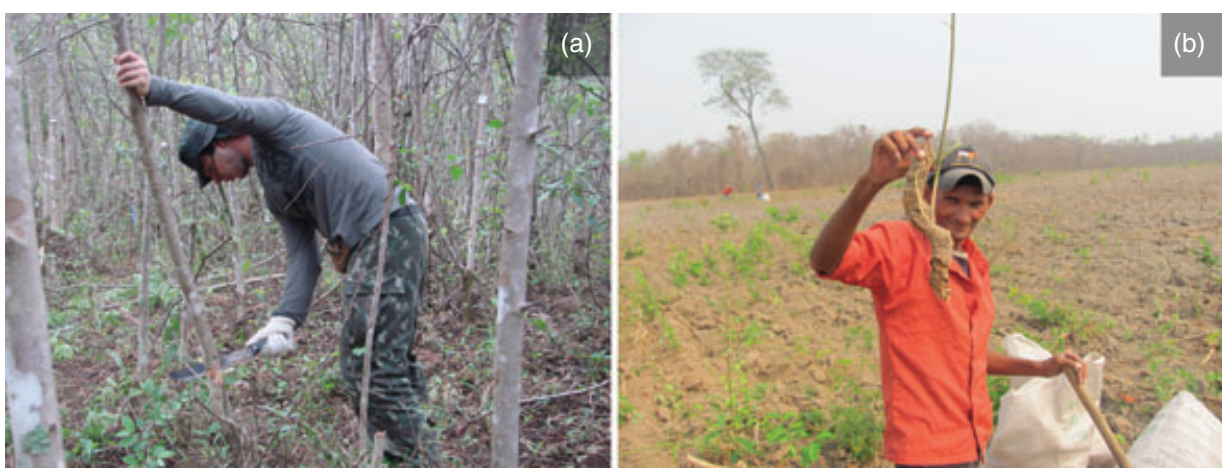

Figure 1. (a) Pole cutting harvest in an early successional dry forest. (b) Root cutting collection in a pasture after plowing to reseed.

Table 1. Studied species and number of pole cuttings used in experiments 1 (first six species) and 3 (Spondias mombin).

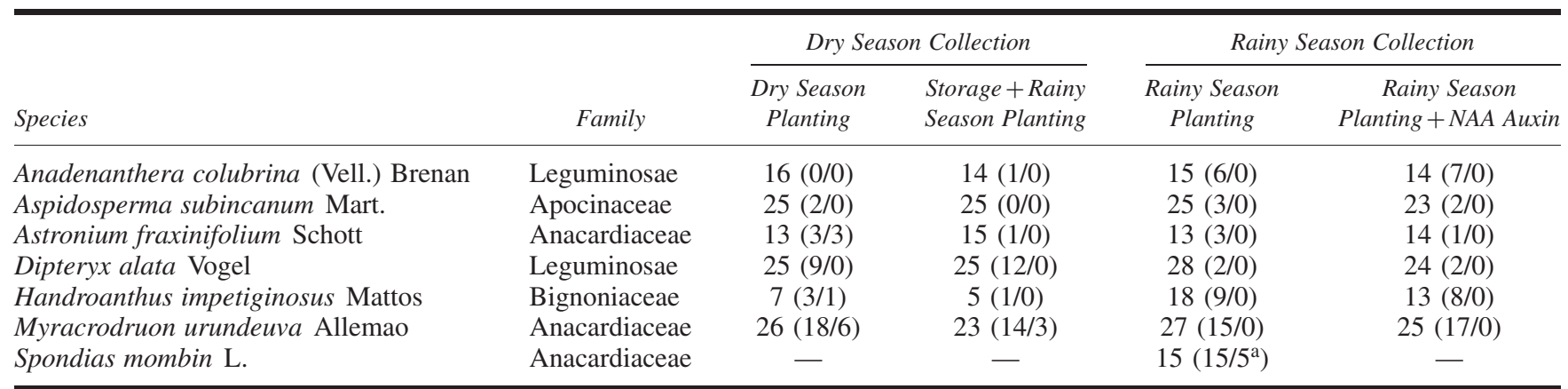

Numbers in parentheses correspond to cuttings with new shoots/cuttings rooting after 150 days.

${ }^{a}$ Only five cuttings of $S$. mombin were dug to check for rooting.

Stem cuttings were collected in the late dry season $(7-10$ October 2010; leafless individuals) or early rainy season (11-13 November 2010; flushing individuals). Cuttings collected in the late dry season were either (1) planted directly in pots without irrigation or (2) stored in the shade of a dense tree canopy, with the bases covered by $10 \mathrm{~cm}$ of moist soil (frequently watered), and planted in November 2010 in the early rainy season. Cuttings collected in the early rainy season were planted 5 days after collection either (3) without hormones or (4) after treatment with a water solution of $200 \mathrm{mg} / \mathrm{L}$ of auxin NAA ( $1 \mathrm{~g} / \mathrm{L}$ of the commercial product Radimaxi $20^{\circledR}$, Fertsana Especialidades Agrícolas Ltda EPP, Sao Paulo, Brazil) for $18 \mathrm{~h}$ (Table 1). Greenhouse irrigation started only after all cuttings were planted, on 15 November 2010, which is the median day of the beginning of the rainy season in the region of collection. Afterwards irrigation occurred daily.

\section{Experiment 2: Field Experiment With Pole Cuttings of $M$. urundeuva}

In October 2010 , nine $20 \times 20 \mathrm{~m}$ plots were established in order to fell 0,25 , or $50 \%$ of the M. urundeuva poles in a successional forest in Cumari County (see above). Thinning was used to harvest cuttings and to test the hypothesis of acceleration of secondary succession through thinning (an ongoing separate study). After being placed in the shade for 3 days, 60 cuttings were treated with water solution of $200 \mathrm{mg}$ of NAA auxin/L ( $1 \mathrm{~g} / \mathrm{L}$ of the commercial product Radimaxi
$20^{\circledR}$ ) for $18 \mathrm{~h}, 60$ were placed in water and dusted with IBA auxin 2,000 ppm (commercial product Fertmaxi $2000^{\circledR}$ ), and 60 had no treatment. Cuttings were planted along fences in a pasture, on either a slope or a plateau $2 \mathrm{~km}$ apart (90 cuttings per area). All cuttings were buried $40 \mathrm{~cm}$ deep.

\section{Experiment 3: Greenhouse and Field Experiments With Pole Cuttings of $S$. mombin}

As a way of ensuring that our results were due to species traits and not the method of collection, transportation and planting, we carried out the same protocol used in experiment 1 with cuttings of Spondias mombin, 1 year later. S. mombin is frequently used as a live fence post in Central America (Budowski \& Russo 1993) and in some agro forests in Brazil, where it is propagated by large cuttings (Vieira personal observation). For this experiment, cuttings were collected in the Paranã River Basin in the early rainy season and planted in the greenhouse in the Federal District (same as treatment 3 of experiment $1 ; n=15$ ) or in a pasture (same as experiment 2 ), also in the Federal District $\left(15^{\circ} 55^{\prime} 25^{\prime \prime} \mathrm{S}\right.$ and $48^{\circ} 02^{\prime} 09^{\prime \prime} \mathrm{W}$; $n=63)$.

\section{Experiment 4: Greenhouse Experiment With Root Cuttings of Six Tree Species}

Root cuttings were collected from Astronium colubrina, A. subincanum, fraxinifolium, Handroanthus impetiginosus, 
M. urundeuva (Table 1), and Eugenia dysenterica DC (Myrtaceae). Species selection was based on high abundance of root-crown resprouters in plowed pastures and high economic value for timber or fruit (E. dysenterica). The collection was made in two pastures with a large number of root-crown sprouts 1 month after plowing for reseeding, at the end of the dry season (7-10 October 2010). We dug around the rootcrown sprouts up to $20-30 \mathrm{~cm}$ deep with a mattock and cut the root (Fig. 1b). Roots varied in length $(16-30 \mathrm{~cm})$ and diameter $(1.5-12 \mathrm{~cm})$. The roots were transported in bags filled with straw grass. The time interval between collection and planting was up to 5 days. The root pieces were planted in a greenhouse in the Federal District in a plant bed filled with soil from the collection areas, at a depth of $5 \mathrm{~cm}$, but with one end sticking out of the ground. Root cuttings were irrigated daily from the beginning of the experiment. Although root cuttings were collected during the dry season, they were flushing leaves because plowing stimulated sprouting (Fig. 1b). Immediately after collection, all sprouts were cut, maintaining only the root piece. Half of the root pieces (between 14 and 16) were treated with auxin and the other half received no treatment. We mixed $2,000 \mathrm{mg}$ of auxin NAA (10 $\mathrm{g}$ of Radimaxi $\left.{ }^{\circledR} 20\right)$ with $1 \mathrm{~L}$ of water and clay to make a paste; two-thirds of the each treated root were submersed in the paste and dried in environmental conditions for $18 \mathrm{~h}$ before planting.

\section{Census, Measurements, and Data Analyses}

The number of branches was recorded monthly for the pole cuttings planted in the greenhouse. After 150 days, all cuttings that sprouted (i.e. that had branches) were removed from the pots to measure root and branch mass and the length of the longest root. For this purpose, the pot was cut and roots were separated from soil with a water-spray gun. For $S$. mombin planted in pots, only five cuttings were excavated. New branches and roots were measured, dried to constant mass at $70^{\circ} \mathrm{C}$ and weighed with a precision balance. None of the pole cuttings planted in the field was excavated. In this case, we recorded the number of branches and leaves and the length of the longest branch. Root cuttings were dug up with a small hoe and washed with care. None of the root cuttings produced new roots. Because in most of the treatments species did not sprout roots, it was not necessary neither possible to perform statistical analyses. We followed sprouting for only 150 days in the greenhouse experiments because in dry forest systems plants need to become established within 6 months, before losing leaves and maintaining minimum metabolism for the following 6 months.

\section{Results}

\section{Experiment 1: Greenhouse Experiment With Pole Cuttings} of Six Tree Species

Five out of the six species tested sprouted new shoots by the end of the rainy season (150 days; Table 2). However, only cuttings of M. urundeuva, A. fraxinifolium, and $H$. impetiginosus
Table 2. Number and percentage of Myracrodruon urundeuva cuttings that had sprouts after 5 and 15 months, and mean number of sprouts, size of the longest sprout, and number of leaves at the 15th month.

\begin{tabular}{|c|c|c|c|c|c|}
\hline & \multicolumn{2}{|c|}{$\begin{array}{l}\text { Cuttings Sprouting } \\
\text { Branches Total (\%) }\end{array}$} & \multirow{2}{*}{$\begin{array}{c}\text { Mean } \\
\text { Number } \\
\text { of } \\
\text { Branches }\end{array}$} & \multirow{2}{*}{$\begin{array}{c}\text { Mean Length } \\
\text { of Longest } \\
\text { Branch } \\
(\mathrm{cm})\end{array}$} & \multirow{2}{*}{$\begin{array}{c}\text { Mean } \\
\text { Number of } \\
\text { Leaves }\end{array}$} \\
\hline & 5 months & 15 months & & & \\
\hline \multicolumn{6}{|l|}{ Plateau } \\
\hline Control & $18(58.1)$ & 4 (12.9) & 13 & 19.8 & 14.7 \\
\hline NAA & $12(41.4)$ & $1(3.7)$ & $20^{\mathrm{a}}$ & $12.0^{\mathrm{a}}$ & $25^{\mathrm{a}}$ \\
\hline IBA & $6(22.2)$ & $1(3.5)$ & $5^{\mathrm{a}}$ & $10.0^{\mathrm{a}}$ & $25^{\mathrm{a}}$ \\
\hline \multicolumn{6}{|l|}{ Slope } \\
\hline Control & $22(73.3)$ & $4(13.3)$ & 6 & 21.0 & 30.0 \\
\hline NAA & $22(73.3)$ & $2(6.7)$ & 9 & 25.5 & 30.0 \\
\hline IBA & $16(53.3)$ & $2(6.7)$ & 5 & 21.8 & 24.5 \\
\hline
\end{tabular}

See text for a complete description of treatments.

a Note that values represent only one cutting.

developed roots. Six (23\%) M. urundeuva cuttings rooted in the "dry collection and planting" treatment and three (13\%) in the "dry collection, storing, and planting" treatment. A. fraxinifolium and $H$. impetiginosus rooted only in the "dry collection and planting" treatment (23 and 14\%, respectively; Table 2). M. urundeuva roots weighed between 0.03 and $10.93 \mathrm{~g}$ (dry weight), and the longest root was $2.0-32.5 \mathrm{~cm}$ long (range) in the "dry collection and planting" treatment. A. fraxinifolium roots weighed between 0.17 and $8.65 \mathrm{~g}$ and the longest root was 3-25 cm long. The only cutting of $H$. impetiginosus with roots had $9.94 \mathrm{~g}$ of root mass, and the longest root was $25 \mathrm{~cm}$ long. M. urundeuva and A. fraxinifolium in the "dry collection and planting" treatment had $0.15-137.90 \mathrm{~g}$ and 38.89-102.42 g dry mass of sprouts (branches), respectively, and the $H$. impetiginosus cutting had $4.61 \mathrm{~g}$.

\section{Experiment 2: Field Experiment With Pole Cuttings of $M$. urundeuva}

Of the 180 cuttings planted in the field, $97.5 \%$ had new sprouts in at least one census, irrespective of block and treatment, and up to $73 \%$ of the cuttings had sprouted by the end of the rainy season (150 days after planting). After 15 months, survival (cuttings with branches and leaves) was reduced to only $13 \%$ for the cuttings not treated with auxins, and less than $7 \%$ of the cuttings treated with auxins (Table 2). Mean number of composed leaves varied from 15 to 30 among treatments (Table 2). Although cuttings were not excavated, stems with live branches after 15 months are likely to have rooted.

\section{Experiment 3: Greenhouse and Field Experiments With Pole Cuttings of S. mombin (Control Experiment).}

All the $15 \mathrm{~S}$. mombin pole cuttings sprouted after 150 days in the greenhouse experiment. The five dug cuttings had rooted vigorously, with a mean $6.5 \mathrm{~g}$ (range: $1.3-12.2$ ) of root dry mass, longest root $30.4 \mathrm{~cm}$ (20-51) long, with 5.2 (3-8) branches per cutting and $48.2 \mathrm{~g}(29.9-71.1)$ of branch dry mass. Fifty-five out of 71 cuttings planted in the field $(79 \%)$ 
had sprouts after 150 days. Cuttings had a mean of 28.8 (5-66) composed leaves.

\section{Experiment 4: Greenhouse Experiment With Root Cuttings of Six Tree Species}

All species sprouted in at least one census. By the end of the rainy season (180 days), only cuttings of E. dysenterica were not sprouting. A. subincanum had $23 \%$ of cuttings sprouting without NAA auxin, and $7 \%$ with auxin. M. urundeuva had 20 and 13\%, A. fraxinifolium had 6 and 13\%, H. impetiginosus had 0 and $17 \%$, and A. colubrina had 0 and $7 \%$, respectively. However, no excavated roots showed any sign of new root growth.

\section{Discussion}

The strongest resprouting trees in deforested areas of Brazilian dry forests proved unsuitable for propagation using root and stem cuttings. Our results are not an artifact of the methods we used, because the same methods resulted in high establishment percentage and vigor of Spondias mombin, a species that can be propagated from cuttings (Budowski \& Russo 1993). In fact, our propagation success was higher than observed in another experiment carried out with this species in Mexico, which found at most 70\% of establishment, and only for cuttings planted at the end of the dry season (Zavala 1989). Discovering "good" species for vegetative propagation is a hard task, because there are no clear functional or taxonomic traits correlated to vegetative propagation. We hypothesized that strong resprouters would yield good cuttings. Itoh et al. (2002) studied 62 tree species in Malaysia and found that species with high sprouting ability produced cuttings with significantly longer roots and tended to have a higher percentage of rooting. On the one hand, the species selected for our trial are among the strongest root-crown resprouters of dry forests in central Brazil (Vieira et al. 2006; Sampaio et al. 2007), but did not root from stem and root cuttings. On the other hand, Spondias, a genus commonly planted using large cuttings in Central America (Budowski \& Russo 1993), is rarely observed as root-crown resprouter in pastures and early successional forests (Vieira et al. 2006; Sampaio et al. 2007). This genus occurs in high densities in intact dry forests of Central Brazil (Sampaio \& Scariot 2011), and is occasionally propagated by cuttings in some regions of Brazil. Thus, our study suggests that high resprouting ability is not related to better rooting of cuttings of dry forest species.

The four treatments applied to pole cuttings embraced a range of possibilities of low cost, easy techniques for both farmers and restorationists. Dry season collection and planting was the only treatment in which Astronium fraxinifolium and Myracrodruon urundeuva cuttings rooted (23\%), and resulted in higher root and sprout mass. This is a relatively easy method for planting, given that it does not require storage and auxin treatment. However, with only $23 \%$ of the cuttings becoming established or less if one considers the field experiments (13\% after 15 months; experiment 2), propagation by cuttings is not a recommended practice for these species. Testing different levels of irrigation during the first dry season after planting cuttings could determine if the high mortality after the rainy season (Table 2) is caused by drought. Considering that $8.4 \%$ of the M. urundeuva cuttings were attacked by ants (data not shown), biological control may improve the establishment of cuttings. Both A. fraxinifolium and M. urundeuva are the species with high timber value for conventional dead fence posts. Given that seed availability, seed germination, seedling establishment, and growth rates are all high for these species, they may be planted using seeds or seedlings at low cost (Vieira et al. 2007).

Root cuttings are used around the world to propagate tree species (e.g. Ky-Dembele et al. 2010; Snedden et al. 2010; Tchiagam et al. 2011). The legume tree Detarium microcarpum Guill. \& Perr. has been successfully propagated by root cuttings in Burkina Faso, and it was tested because of its high ability to resprout from roots in agricultural areas (Ky-Dembele et al. 2010). For the same reason, we tested strong root-crown resprouting species of tropical dry forests. Unfortunately, no root pieces rooted in our experiment, showing that it is not simple to propagate these species using this technique. The root harvesting method we used could be improved by reducing damage to root pieces by harvesting when the soil is saturated, but this is not practical in active pastures because the grass is sowed before the onset of the rains, and pastures will be already established by the time the soil becomes saturated. Another option would be to use a heavy plow or subsoiler that could cut and expose the root pieces. In addition, the timing of root collection, after plowing and in the late dry season, was not ideal. By the time the roots were harvested, root reserves had been remobilized to form sprouts. Ultimately, much more research is needed to evaluate the potential for using tree root banks from pasture areas in dry forests. Several aspects must be tested to evaluate the real potential of root pieces for propagation, such as root harvesting methods, root part, root size, timing of collection, storage conditions and period, and application of fungicide and auxins (Ky-Dembele et al. 2010; Snedden et al. 2010; Tchiagam et al. 2011).

Prospecting traditional knowledge seems the best method of species selection for testing, improving, or disseminating technologies of tree cuttings (Budowski and Russo 1993; Choudhury et al. 2005; Zahawi 2005). However, in Brazil the use of live fence posts is rare, so there is little traditional knowledge of potential of species for easy vegetative propagation. In addition, studies focused on describing traditional knowledge of vegetative propagation for live fences or accelerated species reproduction are rare (Nascimento et al. 2009). In fact, in Brazil, the reports that recommend species for large cuttings to establish live fence posts emphasize exotic species, such as Gliricidiasepium (Jacq.) Kunth ex Walp. and Leucaena leucocephala (Lam.) de Wit, and include few native species, namely Cedrela fissilis Vell., Pseudobombax grandiflorum (Cav.) A.Robyns, Schinus terebinthifolius Raddi, and the genus Erythrina (Miranda \& Valentim 1998; Baggio \& 
Vilcahuaman 2000). Apart from these recommendations, there are few studies on cuttings from native species, namely species of the genus Spondias Souza \& Araújo (1999) and Pachiraglabra Pasq (syn. Bombacopsis glabra (Pasq.) A.Robyns) Carmo (2006).

Pasture establishment is responsible for most of the deforestation in tropical dry forests of central Brazil, as well as in Latin America in general. Fortunately, there is a growing effort to promote sustainable systems of livestock production through the adoption of silvopastoral systems and forest restoration RAS (2010). Developing methods to manage natural regeneration and to transfer root and stem cuttings are promising avenues of research, especially in regions where the potential of natural regeneration is still high, such as recently colonized regions, resilient, and resistant ecosystems, and areas where agriculture is not highly industrialized.

\section{Implications for Practice}

- Strong resprouting ability after disturbance does not mean that a species is sound for vegetative propagation by large stem cuttings and root cuttings.

- Root cuttings need to be investigated for harvesting techniques, choice of root part, root size, timing of collection, storage conditions and length, and fungicide and auxin treatments before predicting their success.

- Prospecting traditional knowledge might be the most effective method of species selection for testing technologies of tree cuttings.

\section{Acknowledgments}

We thank Nilton, Daniel Agroflor, Danny, Aelton, Rafael, Careca, and Preto for cutting collection and planting. In Catalão, it was enriching having 18 students from the community ecology course at University of Goiás (Campus Catalão), brought by Prof. Hélder Consolaro. We thank A. Sampaio and B. Baker-Méio for English editing and valuable comments on an early version of this manuscript. CNPq supported this work through the grant (MCT/CNPq 14/2009 - Universal Proc. 475409/2009-4). A.G.C. had a CNPq scholarship.

\section{LITERATURE CITED}

Baggio, A. J., and L. J. M. Vilcahuaman 2000. Manual prático sobre mourões vivos. Documento - Embrapa Florestas 48 (available from http://www. cnpf.embrapa.br/publica/seriedoc/edicoes/doc48.pdf) [accessed on 17 May 2012].

Borchert, R. 1994. Induction of rehydrataction and bud break by irrigation or rain in deciduous trees of a tropical dry forest in Costa Rica. Trees 8:198-204.

BRASIL. 1983. Projeto RADAMBRASIL, Levantamento de Recursos Naturais, Vol. 31 Folha SD.22 Goiás. Ministério das Minas e Energia, Departamento Nacional de Produção Mineral (DNPM), Rio de Janeiro, Brazil.

Budowski, G., and R. O. Russo. 1993. Live fence posts in Costa-Rica - a compilation of the farmer beliefs and technologies. Journal of Sustainable Agriculture 3:65-87
Carmo, V. B. do. 2006. Utilização da castanheira da praia [Bombacopsis glabra (Pasq.) A. Rob.] como mourão vivo pelas comunidades açorianas da Ilha de Santa Catarina. Master's Dissertation. Programa de Pós-Graduação em Agroecossistemas, Centro de Ciências Agrárias, Universidade Federal de Santa Catarina.

Choudhury, P. R., P. Rai, U. S. Patnaik, and R. Sitaram. 2005. Live fencing practices in the tribal dominated Eastern Ghats of India. Agroforestry Systems 63:111-123.

de la Cerda, I. G. 1999. Tropical rain forest trees propagated using large cuttings (Nicaragua). Ecological Restoration 17:84-85.

Hartmann, H. T., and D. E. Kester. 1975. Plant propagation: principles and practices. 3rd edition. Prentice-Hall Inc., Englewood Cliffs, New Jersey.

Itoh, A., T. Yamakura, M. Kanzaki, T. Ohkubo, P. A. Palmiotto, J. V. Lafrankie, J. J. Kendawang, and H. S. Lee. 2002. Rooting ability of cuttings relates to phylogeny, habitat preference and growth characteristics of tropical rainforest trees. Forest Ecology and Management 168:275-287.

Ky-Dembele, C., M. Tigabu, J. Bayala, P. Savadogo, I. J. Boussim, and P. C. Oden. 2010. Clonal propagation of Detarium microcarpumfrom root cuttings. Silva Fennica 44:775-786.

Latt, C. R., P. K. R. Nair, and B. T. Kang. 2001. Reserve carbohydrate levels in the boles and structural roots of five multipurpose tree species in a seasonally dry tropical climate. Forest Ecology and Management 146: $145-158$.

Lebude, A. V., B. Goldfarb, F. A. Blazich, F. C. Wise, and J. Frampton. 2004. Mist, substrate water potential and cutting water potential influence rooting of stem cuttings of loblolly pine. Tree Physiology 24:823-831.

Miranda, E. M., and J. F. Valentim 1998. Estabelecimento e manejo de cercas vivas com espécies arbóreas de uso múltiplo. Comunicado Técnico n. 85. Embrapa Centro de Pesquisa Agroflorestal do Acre, Rio Branco, Brasil (available from http://www.infoteca.cnptia.embrapa.br/bitstream/doc/ 495108/1/comunicado85.pdf) [accessed on 17 May 2012].

Mostacedo, B., F. E. Putz, T. S. Fredericksen, A. Villca, and T. Palacios. 2009. Contributions of root and stump sprouts to natural regeneration of a logged tropical dry forest in Bolivia. Forest Ecology and Management 258:978-985.

Nascimento, V. T., L. G. Sousa, A. G. C. Alves, E. L. Araújo, and U. P. Albuquerque. 2009. Rural fences in agricultural landscapes and their conservation role in an area of caatinga (dryland vegetation) in Northeast Brazil. Environment, Development and Sustainability 11:1005-1029.

Newell, E., S. S. Mulkey, and J. S. Wright. 2002. Seasonal patterns of carbohydrate storage in four tropical tree species. Oecologia 131:333-342.

Perrando, E. R., and M. P. M. Corder. 2006. Resprouting of Acacia mearnsii stumps under different ages, seasons and cut heights. Pesquisa Agropecuaria Brasileira 41:555-562.

RAS 2010. (Red de Agricultura Sostenible). Norma para Sistemas Sostenibles de Producción Ganadera. Segunda versión para consulta pública, Enero de 2010. (available from http://www.rainforest-alliance.org/agriculture/ documents/sust_ag_standard_pt.pdf) [accessed on 17 May 2012]

Ratter, J. A. 1992. Transitions between cerrado and forest vegetation in Brasil Pages 51-76 in P. A. Furley, J. Proctor and J. A. Ratter, editors. Nature and dynamics of forest-savanna boundaries. Chapman \& Hall, London.

Rios, S. E., M. C. Pereira, L. S. Santos, T. C. Souza, and V. G. Ribeiro. 2012. Concentrações de ácido indolbutírico, comprimento e época de coleta de estacas, na propagação de umbuzeiro. Revista Caatinga 25:52-57.

Sampaio, A. B., and A. Scariot. 2011. Efeito de borda na diversidade, composição e estrutura da comunidade arbórea em uma floresta estacional decidual no Brasil Central. Revista Árvore 35:1121-1134.

Sampaio, A. B., K. D. Holl, and A. Scariot. 2007. Regeneration of seasonal deciduous forest tree species in long-used pastures in Central Brazil. Biotropica 39:655-659.

Snedden, J., S. M. Landhausser, V. J. Lieffers, and L. R. Charleson. 2010. Propagating trembling aspen from root cuttings: impact of storage length and phenological period of root donor plants. New Forests 39:169-182.

Souza, F. X. de, C. A. T. Araújo 1999. Avaliação dos métodos de propagação de algumas Spondias agro-industriais. Comunicado técnico n. 31. Embrapa Agroindústria Tropical, Fortaleza, Brasil. 
Tchiagam, J. B. N., J. P. Ndzie, R. Bellefontaine, and P. M. Mapongmetsem. 2011. Vegetative propagation of Balanites aegyptiaca (L.) Del., Diospyros mespiliformisHochst. ex. A. Rich. and Sclerocarya birrea (A. Rich.) Hochst. in northern Cameroon. Fruits 66:327-341.

Vieira, D. L. M., A. Scariot, A. B. Sampaio, and K. D. Holl. 2006. Tropical dry-forest regeneration from root suckers in Central Brazil. Journal of Tropical Ecology 22:353-357.

Vieira, D. L. M., A. Scariot, and K. D. Holl. 2007. Effects of gap, cattle and selective logging on seedling survival and growth in dry forests of Central Brazil. Biotropica 39:269-274.

Vieira, D. L. M., and A. Scariot. 2006. Effects of logging, liana tangles and pasture on the seed fate of dry forest tree species. Forest Ecology and Management 230:197-205.
Zahawi, R. 2005. Establishment and growth of living fence species: an overlooked tool for the restoration of degraded areas in the tropics. Restoration Ecology 13:92-102.

Zahawi, R., and K. D. Holl. 2009. Comparing the performance of tree stakes and seedlings to restore abandoned tropical pastures. Restoration Ecology 17:854-864.

Zavala, M. L. 1989. Supervivencia de especies forestales tropicales para cercos vivos, bajo diferentes condiciones de drenaje en tabasco. Bachelor thesis, Division de Ingenieria, Universidad Autonoma Agraria "Antonio Narro," México. 